\title{
THE COAGULATION OF HUMAN BLOOD
}

\author{
By J. F. Ackroyd, M.B., M.R.C.P. \\ The Medical Unit, St. Mary's Hospital, London, W.2
}

The classical theory of blood coagulation advanced by Schmidt (1892) and Morawitz (1905) is represented schematically in Fig. I. This theory has stood the test of time and repeated experimental investigation, and it is on this foundation that all further hypotheses must be built.

Conclusive proof that blood coagulation involved other factors in addition to those included in the classical theory was first provided by Owren's (1944, 1947) discovery of factor V, although it is clear that Nolf's (1908) work, which had largely been overlooked, had anticipated Owren's discovery by many years. Owren's factor V, which was soon to be rediscovered independently by Fantl and Nance (1946) and by Ware, Guest and Seegers (1947), stimulated widespread interest in the factors concerned in blood coagulation with the result that numerous new coagulation factors, some hypothetical and inadequately supported by experimental evidence, have been postulated. It is the purpose of this short article to describe very briefly the more important properties of the factors included in the classical theory of blood coagulation; to describe the action of those newly discovered factors whose existence seems adequately established; and to

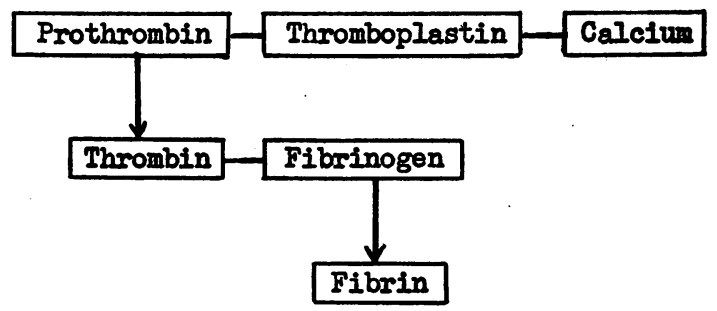

Fig. 1.-The classical theory of blood coagulation.

outline some of the more important observations that led to their discovery. Finally an attempt will be made to show how they, and the older estabo lished factors, interact to cause coagulation of the blood. As many of the coagulation factors have been given different names by different workers, $\overrightarrow{\mathbf{a}}$ list of some of the more commonly used synonyms is given in Table $\mathrm{I}$.

\section{The Factors Recognized in the Classical Theory \\ Tissue Thromboplastin}

Tissue extracts have been known for many years to hasten the coagulation of blood or plasma. They act by accelerating the conversion of prothrombin

TABLE I

Commonly Used Synonyms for Coagulation Factors

Thrombogen (Nolf) Factor V (Owren)

Labile factor (Quick)

Prothrombin accelerator (Fantl and Nance)

Proaccelerin $\longrightarrow$ accelerin (Owren)

Plasma Ac. globulin. $\rightarrow$ Serum Ac. globulin (Seegers)
Stable component (Stefanini)

FACTOR VII (Koller)

Co-factor V (Owren)

Prcconvertin $\longrightarrow$ convertin (Owren)

Serum prothrombin conversion accelerator (S.P.C.A.) (Alexander and de Vries)

Prothrombin conversion factor (Owen and Bollman)

Co-thromboplastin (Mann and Hurn)

Plasma Thromboplastin Component (P.T.C.)

(Aggeler, White, Glendenning, Page, Leake and Bates) (Lewis, Tagnon, Davidson, Minot and Taylor)

Thromboplastinogen (Quick)

Thrombocytolysin (Brinkhous)

Plasma thromboplastic factor (Stefanini)

Factor VIII (Koller) 
to thrombin. This activity depends to a considerable extent upon the concentration of calcium in the mixture (Biggs and Macfarlane, 1953a). The active principle of the extracts, thromboplastin, is particulate, and can be removed by centrifugation at relatively low speeds (3 I,000 g.) (Chargaff et al., 1944). It can be obtained from almost any tissue in the body, brain and lung being the most commonly used. Thromboplastin will accelerate clotting even when diluted as much as I:100,000. It seems probable, therefore, that it acts as a catalyst. Thromboplastin will not clot fibrinogen solutions or preparations of plasma from which the prothrombin has been removed.

\section{Plasma Thromboplastin}

Blood will clot in glass vessels without admixture with tissue extracts and must therefore, according to the classical theory, contain thromboplastin. It has generally been believed that this came from the platelets. These, however, contain relatively little, but as will be shown later, they are essential for normal thromboplastin formation.

\section{Prothrombin and Thrombin}

These have been prepared in a highly purified state by Seegers, McClaughry and Fahey (1950). They are proteins. 90 per cent. of the prothrombin moves electrophoretically with a mobility of $\alpha_{1}$ globulin. The mobility of thrombin is slightly less. Purified prothrombir is converted into thrombin when dissolved in 25 per cent. sodium citrate. It therefore seemsireasonablec to conclude that prothrombin contains all the structural material needed for the formation of thrombin (Seegers et al., 1950). The action of thrombin in converting fibrinogen to fibrin appears to be enzymatic, for thrombin will convert many times its weight of fibrinogen. This action is accelerated by calcium (Biggs and Macfarlane, I953a), and by platelet extracts (Ware, Fahey and Seegers, 1948).

\section{Fibrinogen and Fibrin}

Fibrinogen is a protein with an elongated molecule about $800 \AA$ in length and $40 \AA$ in width. Fibrin appears to be formed by the polymerization of individual fibrinogen molecules. Electron microscopic studies suggest that an end to end linkage of fibrinogen molecules occurs forming fibrils which later aggregate into bundles which constitute the individual fibrin strands.

\section{Recently Discovered Coagulation Factors Coagulation Factors in Plasma and Serum Factor $V$}

The existence of this factor was first established by Owren's (1944, 1947) brilliant analysis of the abnormality of blood coagulation in a patient with a hitherto undescribed haemorrhagic disease which Owren called parahaemophilia. This patient had a history of abnormal bleeding since the age of $3 \frac{1}{2}$ years. The whole blood clotting time was prolonged, on one occasion having been as long as 70 minutes. The prothombin time by Quick's (1935) one-stage method was also prolonged.

In this test the coagulation time of oxalated plasma is measured after the addition of optimal concentrations of calcium chloride and brain thromboplastin. On the basis of the classical theory, if the plasma contains an adequate amount of fibrinogen, and calcium and thromboplastin are present in optimal concentrations, then the coagulation time should be inversely proportional to the concentration of prothrombin. The prolonged coagulation time with this test should therefore have indicated that the prothrombin content of this patient's plasma was reduced. Owren found, however, that the prothrombin time could be greatly shortened by the addition of normal plasma from which the prothrombin had been removed by adsorption on to aluminium hydroxide, or by Seitz filtration. It seemed clear, therefore, that this patient's plasma lacked a substance which is present in normal plasma and which is left in the plasma after removal of the prothrombin. Owren called this substance factor $\mathrm{V}$. He described a method for its partial purification and showed that it was necessary for the rapid conversion of prothrombin to thrombin, and that it disappeared rapidly from the blood after clotting. The prolonged prothrombin time observed with the blood of his patient was clearly due to the slow and incomplete formation of thrombin resulting from the absence of factor $\mathrm{V}$ from the plasma.

Several other cases of factor $\mathrm{V}$ deficiency have now been described (Frank, Bilhan and Ekren, 1950; de Vries, Matoth and Shamir, I95I; Stohlman, Harrington and Moloney, I95I; Brink and Kingsley, 1952; Cosgriff and Leifer, 1952; Owren, 1953). In some of these cases there was a familial incidence of the disease.

Shortly after Owren had announced his discovery, Fantl and Nance (1946) and Ware, Guest and Seegers (1947), working independently with purified preparations of prothrombin, described experiments which demonstrated the existence of a factor required for the rapid conversion of prothrombin to thrombin. These workers found that although prothrombin prepared by salt precipitation rapidly formed thrombin in the presence of calcium and thromboplastin, yet prothrombin prepared by adsorption on to aluminium hydroxide and subsequent elution, was only converted to thrombin very slowly. The rate of conversion could be accelerated by the addition of a small 
quantity of the plasma from which the prothrombin had been adsorbed. The factor responsible was partially purified by both groups of workers. Fantl and Nance (1948) called the factor prothrombin accelerator, while Ware and Seegers (1948) gave it the name Ac globulin. There seems little doubt that these factors are identical with Owren's factor V, and Owren's term will therefore be used hereafter. The labile factor which disappears from oxalated plasma on storage, and which was described by Quick in 1943, is probably also identical with factor $\mathrm{V}$, although it must be stated that the clotting defect produced by storage is not a clearly defined entity, and that storage almost certainly alters factors other than factor V in plasma. Ware, Fahey and Seegers (1948) have shown that platelets, as well as plasma, have factor $\mathrm{V}$ activity.

\section{Factor VII}

That there is another factor in addition to factor $\mathrm{V}$ which is responsible for accelerating the conversion of prothrombin to thrombin was first suggested by Owen and Bollman (1948). They were investigating Schofield's (1924) observation that spoiled sweet clover disease in cattle (which is due to the presence of dicoumarol in the fodder) is improved by the injection of normal serum. This condition was believed to be due solely to a reduction in plasma prothrombin which was unlikely to have been significantly increased by the administration of serum which normally contains little or no prothrombin. These authors therefore investigated the blood of dogs fed on, or injected intravenously with, dicoumarol. They found that the plasma prothrombin, as estimated by the onestage method, was greatly reduced, but that the addition of normal prothrombin free ssrum caused a considerable rise in the apparent prothrombin level as indicated by this test. They concluded from this and other experiments that normal serum contains a factor necessary for prothrombin conversion. This factor is unlikely to have been factor $\mathrm{V}$ because factor $\mathrm{V}$ disappears rapidly from serum (Owren, 1947) and also because factor $\mathrm{V}$ is not significantly reduced in the plasma of patients receiving dicoumarol (Owren, 1950b). The factor described by Owen and Bollman appears, therefore, to be a further prothrombin conversion factor.

In 1949, de Vries, Alexander and Goldstein observed that oxalated serum, in the presence of calcium and thromboplastin, accelerates the coagulation of oxalated plasma. This occurred if the oxalated plasma was diluted with plasma which had been adsorbed with barium sulphate to remove most of its prothrombin whilst leaving an excess of factor $V$. They therefore considered that the serum contained a new coagulation factor which they have partially purified (Alexander. Goldstein and Landwehr, 1950), and which they call serum prothrombin conversion accelerator (S.P.C.A.). They showed that dicoumarol causes a reduction in both plasma prothrombin and the serum prothrombin conversion accelerator (Alexander, de Vries and Goldstein, 1949).

In 1950 Owren (I950a) showed that thrombin was formed when human serum was added to Seitz filtered ox plasma in the presence of calcium and thromboplastin. He thought at first that the prothrombin must be in the serum but later showed that it was in the ox plasma which had been inadequately filtered (Owren, 1950a; 1951). This remaining prothrombin was not converted to thrombin by calcium, thromboplastin and factor $\mathrm{V}$ alone. Owren therefore concluded that the serum must contain a further factor necessary for prothrombin conversion, and that this factor had been adsorbed from the plasma by Seitz filtration. It is also adsorbed by aluminium hydroxide (Biggs, Douglas and Macfarlane, 1953a). Owren called this factor Convertin. It seems almost certain that it is identical with the factor described by Owen and Bollman (1948) and the serum prothrombin conversion accelerator of Alexander and his coworkers (1949, 1950).

Koller and his colleagues (195 I, 1952) have re peated Owren's experiments and have shown conclusively that this factor accelerates the conversion of prothrombin to thrombin. They call it factor VII, factor VI being the name given by Owr 2 n to a hypothetical substance derived from factor $\mathrm{V}$.

The importance of this factor, which will hereafter be referred to as factor VII, was finally established by Alexander and his co-workers (195I) who described a patient with a haemorrhagic syndrome apparently due to a congenital deficiency of the factor. The disease was characterized by a normal whole blood clotting time and a prolonged one-stage prothrombin time which was corrected in vitro by the addition of crudely purified factor VII and temporarily, in vivo, by the intravenous administration of human serum. The factor $V$ content of the patient's plasma was shown to be normal. Similar cases have recently been reported by Beaumont and Bernard (1953) and by Jürgens (I953); and Owren (1953) has described a family of which several members were affected by this condition.

Further studies have shown that deficiency of this factor is the main abnormality caused by tromexan therapy (Douglas, 1953). It is also reduced in advanced liver disease and in the newborn ( $\mathrm{de}$ Nicola, 1953).

Factor $X$

The existence of this factor has recently been 
postulated by Koller (1.953) who found that if factor VII was prepared in a sufficiently pure state it lost its power completely to correct the coagulation defect of the blood of patients receiving tromexan. He suggested that crude factor VII contained two factors: factor VII and a new factor which he called factor X, factors VIII and IX being antihaemophilic globulin and P.T.C. (Christmas factor) respectively. Koller found that factor $\mathrm{X}$, like factor VII, is present in high concentration in serum, and is reduced in advanced liver disease, in the newborn, and in the blood of patients receiving dicoumarol and tromexan. He believes that he has seen a case of congenital factor $\mathrm{X}$ deficiency.

\section{Antihaemophilic Globulin}

Haemophilia is inherited as a sex-linked recessive character, although sporadic cases, resulting from spontaneous mutation, frequently occur. The blood characteristically shows a prolonged clotting time although this is not an essential feature of the disease. The one-stage prothrombin time is normal and there is an impaired conversion of prothrombin to thrombin during coagulation.

It has been known for many years that the clotting time could be reduced to normal by the addition of thromboplastin or of small quantities of normal plasma (Weil, I906; Addis, I9II; Govaerts and Gratia, 193I). These findings strongly suggest that haemophilia is caused by deficient formation of thromboplastin, and that this results from the absence of some factor present in normal plasma. This factor appears to be utilised during coagulation and is almost absent from normal serum. It is not adsorbed by aluminium hydroxide (Biggs et al., 1952) or barium sulphate (Rosenthal et al., I 953). It occurs mainly in Cohn's plasma fraction I, which also contains the fibrinogen (Cohn, I946). It will be referred to below as the antihaemophilic globulin. Factor V (Owren, r947) and factor VII (Owren, 1950a) are present in normal concentration in haemophilia.

\section{Plasma Thromboplastin Component (P.T.C.) or Christmas Factor}

Pavlovsky, in 1947 , observed the surprising fact that occasionally a patient is found suffering from what is apparently classical haemophilia, whose blood or plasma has the power to reduce the clotting time of the blood of another haemophilic patient.

Three years later Koller and his colleagues (1950) reported the results of their investigations on a patient who seems to have been a further example of the condition described by Pavlovsky. Since then further cases have been reported by
Aggeler and his co-workers (1952), Schulman and Smith (1952), Biggs, Macfarlane and Dacie and their colleagues (Biggs et al., r952), Poole (1953), Lewis and Ferguson (1953) and by Cramer, Matter and Loeliger (1953).

The clinical picture in all these cases was indistinguishable from that of haemophilia. The condition is inherited as a sex-linked recessive character, although sporadic cases occur. As in haemophilia, the coagulation time is usually prolonged. The one-stage prothrombin time is normal, although the conversion of prothrombin to thrombin during coagulation is reduced. The condition is not due to a deficiency of antihaemophilic globulin, for the plasma of these patients reduces the clotting time of haemophilic plasma. The clotting time of the plasma of these patients is reduced by normal and by haemophilic plasma, but not by antihaemophilic globulin (Biggs et al., 1952).

Investigation of the factor concerned shows that, unlike anti-haemophilic globulin, it is present in large amounts in normal serum. It is removed from normal serum or plasma by adsorption on to aluminium hydroxide, or by Seitz filtration (Biggs and Macfarlane, 1953a), or by adsorption on to barium sulphate (Rosenthal et al., I953). In these respects it resembles factor VII. That it is distinct from factor VII is shown by the following observations: (I) Its deficiency does not cause prolongation of the one-stage prothrombin time. (2) Serum from patients deficient in the factor corrects the coagulation defect of the plasma of patients receiving tromexan. (3) The coagulation defect in patients deficient in the factor is corrected by some serum samples from patients receiving tromexan (Biggs and Macfarlane, 1953a).

As the one-stage prothrombin time of the plasma of patients deficient in this factor is normal, it appears that brain thromboplastin rectifies the defect, and therefore that this factor, like antihaemophilic globulin, must be concerned in the formation of thromboplastin. The factor has been partially purified by Aggeler and his colleagues (1952), who have called it the plasma thromboplastin component (P.T.C.). Macfarlane and Dacie and their co-workers (Biggs et al., 1952) have called it the Christmas factor after the first patient in whom they found it to be deficient. Both terms will be used when the factor is referred to below.

\section{Plasma Thromboplastin Antecedent (P.T.A.)}

Rosenthal, Dreskin and Rosenthal (1953) have recently reported a family of which three members had a mild haemorrhagic disease which resembled haemophilia except for the fact that two of those affected were females. The clotting time was pro- 
longed and there was an abnormal utilization of prothrombin. The one-stage prothrombin time was normal. The abnormality was corrected by the addition of blood from patients with either haemophilia or with P.T.C. deficiency (Christmas disease). It appears therefore that this condition may be due to deficiency of a third factor which these authors have called plasma thromboplastin antecedent (P.T.A.). According to Rosenthal and his colleagues, the three conditions can readily be distinguished as follows: The clotting defect in haemophilia is corrected by normal plasma adsorbed with barium sulphate, but not by normal serum; P.T.C. deficiency is corrected by normal serum, but not by barium sulphate adsorbed plasma; and P.T.A. deficiency is corrected by both normal serum and normal plasma which has been adsorbed with barium sulphate.

\section{Plasma Thromboplastin}

One of the main problems in understanding blood coagulation on the basis of the classical theory is the origin of thromboplastin. As blood taken by vein puncture, without contamination with tissue juices, clots readily when placed in a glass vessel, it is clear that blood contains all the factors necessary for coagulation. The platelets have usually been assumed to be the origin of the thromboplastin under these conditions, but platelets, in fact, contain very little (Ware, Fahey and Seegers, 1948). The addition of platelets to recalcified oxalated plasma does not reduce its clotting time to less than about 60 to 80 seconds (Biggs and Macfarlane, I953a), whereas with brain thromboplastin it is easily possible to reduce the clotting time to about 12 seconds. Is this weak thromboplastic action sufficient to promote normal coagulation or is there some other source of thromboplastin in normal plasma?

The most convincing demonstration that plasma contains a potent thromboplastin has been provided by the thromboplastin generation test of Biggs and Douglas (1953). In this test plasma is adsorbed with aluminium hydroxide which removes prothrombin, factor VII and P.T.C. (Christmas factor) and, as shown by Koller (I953), probably also factor $\mathrm{X}$, but leaves antihaemophilic globulin and factor $\mathrm{V}$ in the plasma which, in addition, probably contains plasma thromboplastin antecedent (P.T.A.), the factor recently described by Rosenthal and his colleagues (1953). The deficiencies. in the factors other than prothrombin, removed by adsorption with aluminium hydroxide, are made good by the addition of serum freed of both prothrombin and thrombin. Platelets are then added to the mixture. Finally calcium chloride is added and the thromboplastic activity that develops in the mixture is estimated at

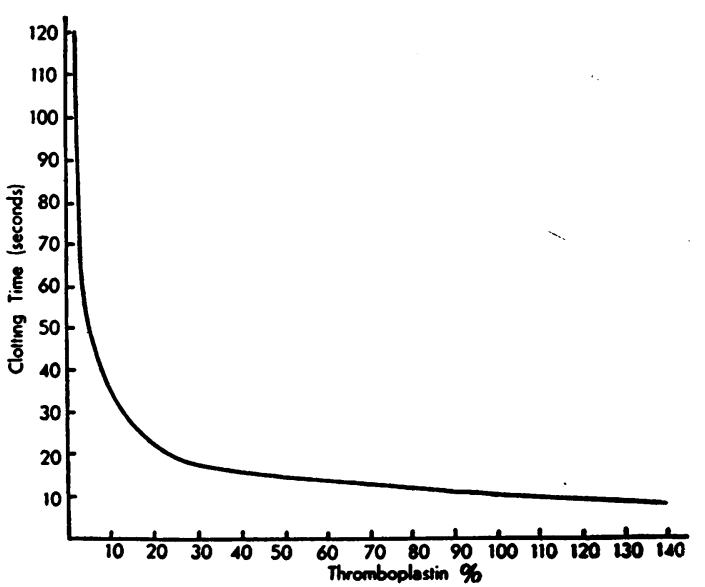

FIG. 2.-Thromboplastin dilution curve. The curve shows the relation between clotting time and thromboplastin concentration.

Reproduced from Biggs and Douglas, f. Clin. Path., 1953, 6, 23, by courtesy of the authors and publishers.

intervals by observing the coagulation time of samples of normal oxalated plasma to which calcium chloride and aliquot quantities of the abovementioned mixture are added. As the mixture contains no significant amount of prothrombin, the coagulation of the normal plasma will be due almost entirely to the thromboplastin developed in the mixture, and the coagulation times will be inversely proportional to the concentration of thromboplastin. Under these conditions thromboplastin forms gradually over a period of 4 to 5 minutes, but when fully developed has a potency at least as great as that of a potent brain extract. By observing the coagulation times with different dilutions of this thromboplastin, a thromboplastin dilution curve can be drawn (Fig. 2) relating clotting time to thromboplastin concentration. The diagram (Fig. 3) shows the thromboplastin concentrations generated in 40 different tests. After five minutes, when the thromboplastin generated in the mixtures was maximal, the mean clotting time of normal plasma to which the mixture was added was less than ro seconds. This is as short, if not shorter, than that obtained with the most potent tissue extracts. It is clear, therefore, that normal plasma contains all the factors required for producing a potent thromboplastin. Moreover, using purified reagents, Biggs, Douglas and Macfarlane (1953b) have shown that all the following components: plateluts, antihaemophilic globulin, P.T.C. (Christmas factor), factor $V$ and factor VII, are required, and that if any one of these factors is missing, abnormal thromboplastin formation will result. The reagents used in these investigations almost certainly contained the re- 


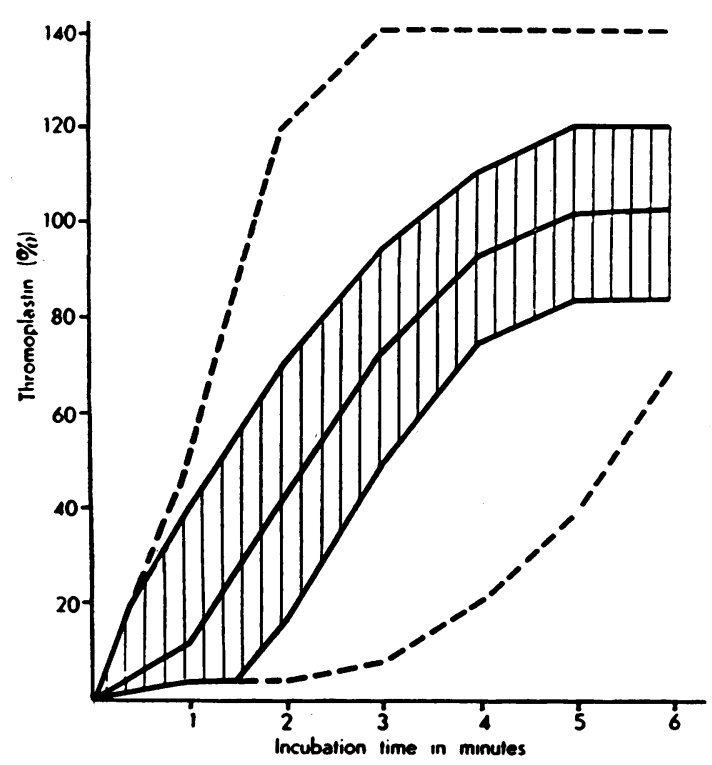

FIG. 3.-The normal range of the thromboplastin generation test. The central curve represents the average of 40 different tests. The shaded area shows the range of variation obtained in 38 of 40 observations in which the adsorbed plasma was obtained from different normal subjects, but serum and platelets were from one subject. The extreme limits show the range of variation when all the reagents are varied simultaneously.

Reproduced from Biggs and Douglas, f. Clin. Path., 1953, 6, 23, by courtesy of the authors and publishers.

cently described factors $\mathrm{X}$ and plasma thromboplastin antecedent (P.T.A.), and it seems probable that these are also necessary for thromboplastin formation.

\section{Coagulation Factors in the Platelets}

The thromboplastin generation test has shown that platelets are necessary for the formation of plasma thromboplastin. Three coagulation factors have been extracted from platelets:

Platelet factor $I$. This was first described by Ware, Fahey and Seegers in 1948. It is found, together with platelet factor II, in watery extracts of platelets. These two factors have since been separated by van Creveld and Paulssen (195I). Platelet factor I has an activity resembling that of factor $\mathrm{V}$ of normal plasma, but unlike factor $\mathrm{V}$ it is particulate and can be made to sediment by centrifuging at about $32,000 \mathrm{~g}$.

Platelet factor II. This accelerates the clotting of fibrinogen by thrombin.

Platelet factor III. This is insoluble in water. When suspended in plasma it antagonizes the action of heparin and has thromboplastic activity. This factor was first described by van Creveld and Paulssen (1951, 1952).
So far no attempt appears to have been made to discover which of these factors is utilized in the generation of plasma thromboplastin. The properties of factors I and III suggest that these must be required, but it is not known whether these alone are sufficient or whether the platelets have still other properties which are also involved.

In thrombocytopenic purpura, presumably because there are insufficient platelets to permit normal thromboplastin formation, prothrombin conversion is incomplete. Apart from this, the association of a haemorrhagic disease with an abnormality of the platelets has been reported by two groups of workers. van Creveld and Paulssen (I951, I952) have described two cases of a haemorrhagic disorder which they attributed to a partial or complete absence of factor III from the platelets, and Biggs and Douglas (1953), although they made no attempt to assay the platelets for their content of the different platelet factors, were able to show that the platelets in a case of thromboasthenia (Glanzmann) were grossly deficient in their power to form normal plasma thromboplastin when incubated with normal serum and aluminium hydroxide adsorbed plasma.

\section{The Initiation of Blood Coagulation}

If blood is taken from a vein into a silicone lined syringe and is transferred to a silicone lined tube, coagulation may not take place for several hours. If the platelets from such a preparation are removed by centrifugation, the plasma may not clot even if it is transferred to a glass container (Patton, Ware and Seegers, 1948). It seems clear, therefore, that both platelets and contact with a suitable surface are necessary, and it may be surmised that contact precipitates platelet disintegration and so initiates the formation of plasma thromboplastin.

In haemophilia, in which the plasma is deficient in antihaemophilic globulin, the blood may not clot for an hour or more even when it is in contact with glass. Moreover, the platelets in haemophilic blood disintegrate much less rapidly during coagulation than do normal platelets in normal blood (Howell and Cekada, 1926). As plat 1:ts from haemophilic blood, when suspended in normal plasma, in glass vessels, disrupt normally during coagulation (Patek and Stetson, I936), it would seem that the platelets in haemophilia are probably normal, and that antihaemophilic globulin may be concerned with the normal disruption of platelets when these come into contact with a suitable surface.

Further evidence of the importance of contact is provided by the observation that the capacity of serum to accelerate prothrombin conversion is reduced if coagulation is delayed by the use of silicone lined apparatus (Alexander, de Vries and 
Goldstein, 1949; Biggs and Macfarlane, 1953a). This observation was originally interpreted as indicating that factor VII must exist in plasma as a relatively inactive precursor which was activated by contact, for at this time factor VII was the only conversion factor known which existed in equal concentration in serum and plasma (the concentrations of both factor V (Owren, I947) and antihaemophilic globulin (Graham et al., I95I) fall rapidly after coagulation). Subsequently it was realized that P.T.C. (Christmas factor) and probably the recentiy postulated factors $X$ and plasma thromboplastin antecedent (P.T.A.) also exist in high concentration in serum. More recent work has indicated that contact probably has no effect on factor VII (Biggs and Macfarlane, 1953b), and that it activates one or more of the other factors found in serum.

\section{Naturally Occurring Inhibitors of Coagulation Antithrombin}

Normal blood, in addition to its complex mechanisms for producing thrombin, also contains powerful mechanisms for neutralizing it. It has been calculated, from the results of experiments on the addition of purified thrombin to plasma, that $1 \mathrm{ml}$. of normal plasma is capable of neutralizing rapidly the amount of thrombin that would be required to clot $2,000 \mathrm{ml}$. of blood in 15 seconds (Biggs and Macfarlane, 1953a).

Thrombin inactivation depends upon two mechanisms:

I. Adsorption on to fibrinogen. This is the cause of the immediate inactivation of thrombin. The thrombin is not destroyed and can be recovered after lysis of the fibrin (Klein and Seegers, 1950).

2. Neutralization by a constituent of normal plasma, antithrombin, which, except with low concentrations of thrombin, appears to react stoichiometrically with thrombin rendering it inert (Klein and Seegers, 1950).

\section{Heparin}

Heparin is a powerful anticoagulant, and although it is not present in the blood in measurable quantity, it can be extracted from most of the tissues of the body, particularly the liver and lungs. There is evidence that it arises from the mast cells. These cells are commonly found along the capillaries suggesting perhaps that they may have some action in preventing local capillary thromboses.

Heparin is inactive in the absence of the albumin fraction of the plasma which contains a substance essential for its action (Quick, 1938). It seems probable that this substance is antithrombin (Lyttleton, 1950).
Heparin appears to have two main actions:

I. It increases the adsorption of thrombin by fibrin (Klein and Seegers, 1950).

2. In association with antithrombin it combines with thrombin, greatly increasing the rate of neutralization of thrombin by antithrombin, but apparently not increasing the amount of thrombin neutralized (Biggs and Macfarlane, 1953a).

According to Biggs and Macfarlane (1953a), when heparin is added to whole blood it delays or prevents the conversion of prothrombin to thrombin. They consider that this effect is probably due to the rapid neutralization of thrombin, this neutralization preventing the autocatalytic effect of thrombin on the development of plasma thromboplastic activity (see below).

\section{Antithromboplastin}

This substance has been postulated by Tocantins but its existence has not yet been finally proved.

\section{Clot Retraction}

When blood clots, the clot occupies a volume equal to that of the blood from which it was formed. After a variable period of minutes, the exact time depending mainly on the temperature, the clot begins to retract, extruding serum and a small number of red cells. Clot retraction de응 pends upon the presence in the blood of an adequate number of normal platelets. If the platelets are removed from plasma, either by centrifugation (Arthus and Chapiro, 1908; Le Sourd and Pagniez, I9II) or by lysis (Tocantins, 1934; Ackroyd, 1949a, 1949b), clot retraction is abolished. Tocantins (1934) and Budtz-Olsen (195I) have produced a considerable amount of evidence to show that platelets cause clot retraction by settling on the fibrin threads and later fusing into small masses, so drawing the fibrin strands together. It is not clear what part clot retraction plays in the haemostatic mechanism.

\section{Fibrinolysis}

Normal human blood contains enzymes which, under certain circumstances, become activated and digest fibrin, and sometimss also fibrinogen. The terminology used below is that of Biggs and Macfarlane (1953a).

\section{Plasmin}

This enzyme is found in the globulin fraction of normal human plasma. Its activity is inhibited by the albumin fraction which has therefore been considered to contain a specific inhibitor "antiplasmin.' Plasmin normally exists in the blood in the form of an inactive precursor ' plasminogen.' It can be activated by separation from the albumin fraction of plasma or by the addition to plasma of 
chloroform or bacterial filtrates, the most commonly used being streptokinase which is obtained from certain strains of $\beta$-haemolytic streptococci. Plasmin causes lysis of fibrin and also destroys fibrinogen.

\section{Fibrinolysin}

Human and animal tissues contain an activator ' fibrinokinase' which activates a fibrinolysin which causes lysis of both fibrin and fibrinogen. This enzyme is also found in the globulin fraction of the plasma, but there are reasons for believing that it is not identical with plasmin (Astrup and Permin, 1948).

\section{Fibrinolysis Post Mortem and in Vivo}

Post mortem blood in cases of sudden death is often found to be fluid, the fibrin in the postmortem clots having been liquefied by a fibrinolytic enzyme which attacks only fibrin and not fibrinogen (Mole, 1948).

Fibrinolytic activity is induced in vivo in man by acute anxiety, severe exercise or by injections of adrenalin (Macfarlane and Biggs, 1946; Biggs, Macfarlane and Pilling, 1947). The enzyme concerned differs from plasmin and fibrinolysin in that it does not digest fibrinogen (Bidwell and Macfarlane, 195I). It closely resembles the lysin found post mortem in cases of sudden death. Nothing is known of the mode of activation of either of these enzymes.

\section{The Interaction of the Factors Concerned in Blood Coagulation}

\section{The Formation of Thromboplastin}

The first step in the initiation of blood coagulation under normal circumstances is the formation of thromboplastin. Where there is much contamination with tissue juices these supply thromboplastic activity, although there is evidence that the tissues supply a thromboplastin which is biologically incomplete, and that its activity is increased by the action of factors V and VII (Biggs, Douglas and Macfarlane, r953b).

In the absence of tissue thromboplastin, blood coagulation depends upon the production of intrinsic plasma thromboplastin, the development of which appears to be dependent upon contact with a water-wettable surface. This seems to be necessary for the disintegration of platelets. Platelet disintegration is probably accelerated by antihaemophilic globulin.

Contact is apparently also necessary for the activation of one or more of the factors, other than factor VII, found in high concentration in serum (plasma thromboplastin component (Christmas factor) and probably the recently postulated factors plasma thromboplastin antecedent and factor X).
These 'serum' factors then react with antihaemophilic globulin and the products of platelet disintegration (probably platelet factors I and III) and with factors V and VII, to produce a highly active thromboplastin. This develops slowly at first and does not appear in maximal concentration for 4 to 5 minutes. The mode of its formation is entirely obscure.

\section{Conversion of Prothrombin to Thrombin}

Thromboplastin is essential for the conversion of

THROMBN UNITS

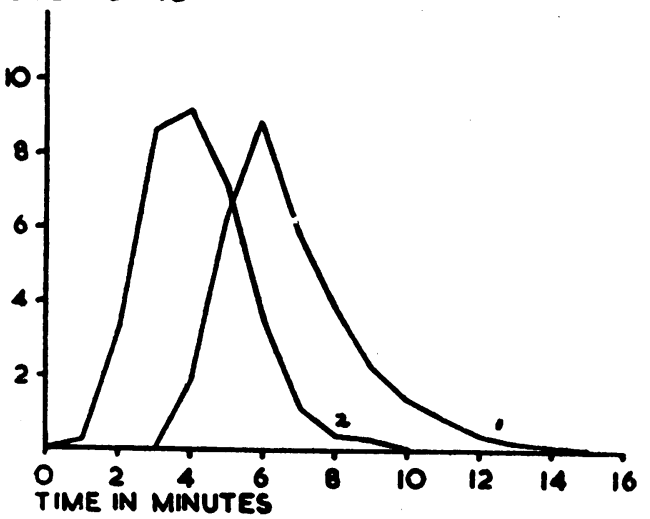

Fig. 4.-Thrombin generation in normal whole blood Curve I: Whole blood alone. Curve 2: Blood to which a small amount of thrombin was added at the beginning of the test.

Reproduced from Macfarlane, Lecture 13 in 'Lectures on the Scientific Basis of Medicine, I951-52,' by courtesy of the author and publishers.

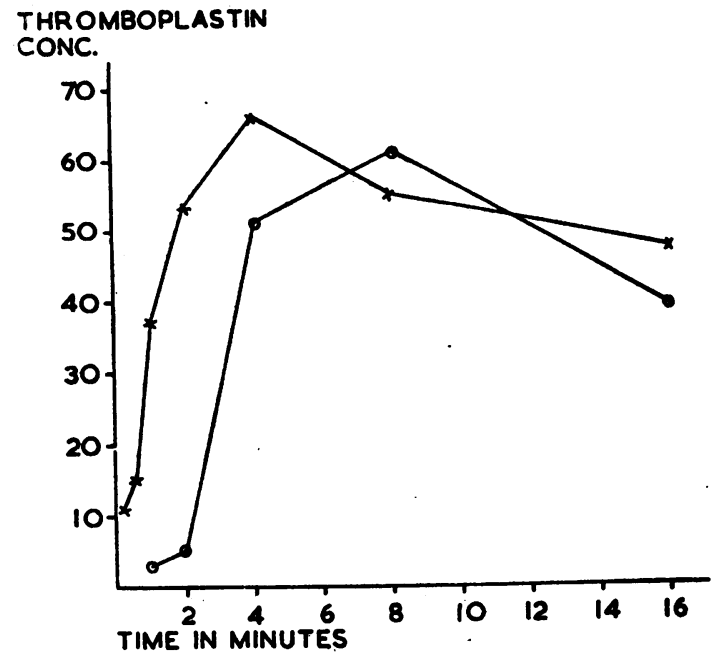

FIG. 5.-The formation of thromboplastin from platelets, aluminium hydroxide adsorbed plasma, normal serum and calcium chloride in the presence $(x-x)$ and absence $(0-0)$ of thrombin.

Reproduced from Biggs and Macfarlane, 'Human Blood Coagulation,' 1953, by courtesy of the authors and publishers 


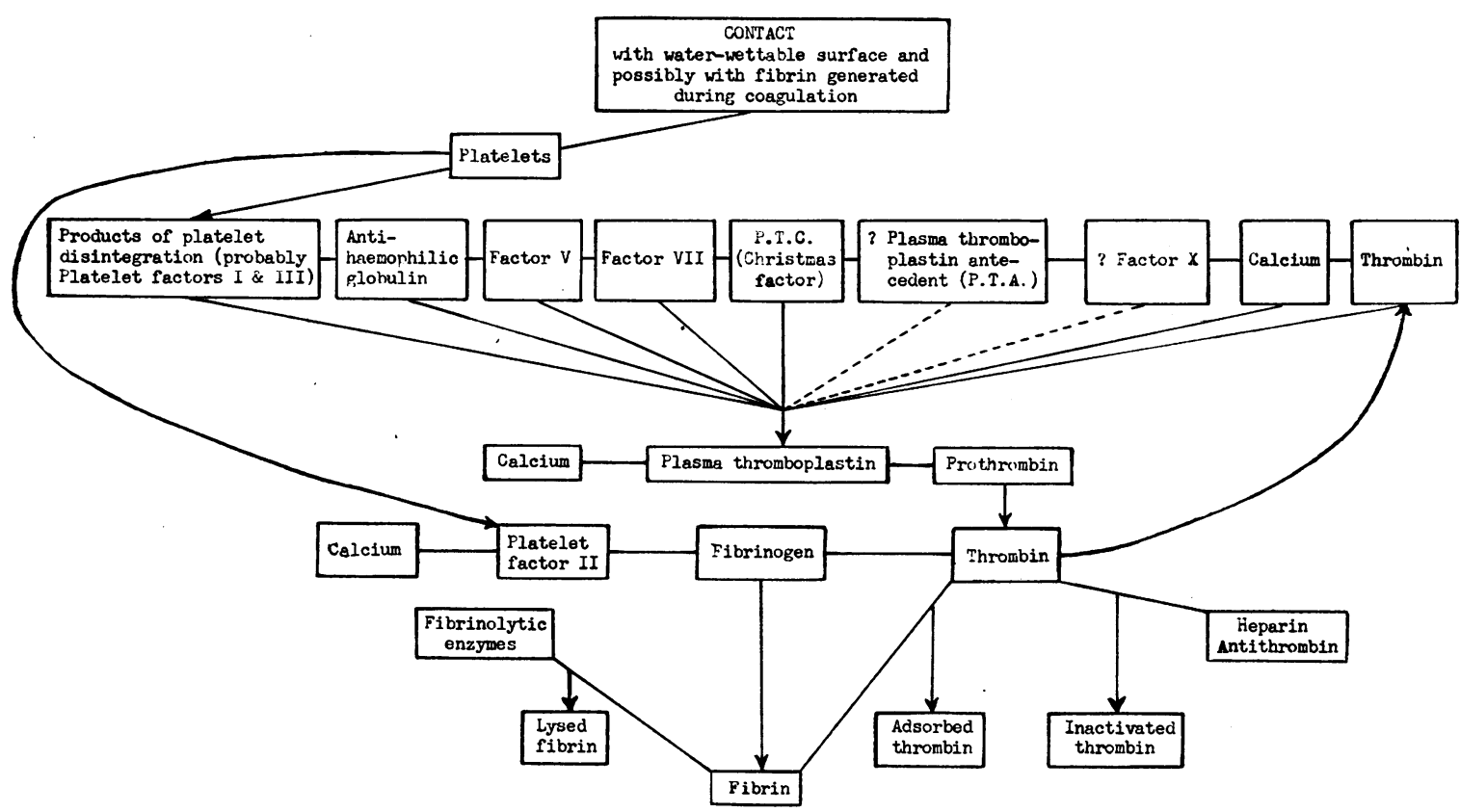

Fig. 6.-The factors concerned in normal blood coagulation.

prothrombin to thrombin during coagulation. It appears to act as a catalyst in this reaction. Thrombin formation can readily be studied by aspirating aliquot quantities of blood during coagulation, and transferring them to solutions of fibrinogen. The thrombin content will be inversely proportional to the clotting time of the fibrinogen. Fig. 4 curve $I$ shows thrombin production during the clotting of normal whole blood. There is a lag period of about 3 minutes before any thrombin appears. It then rapidly increases in amount for a further 3 minutes and then rapidly disappears, the disappearance being due to the action of antithrombin. That thrombin can accelerate its own production is shown by the observation (Fig. 4 curve 2 ) that if a very small amount of thrombin is added to the blood as soon as it is taken, thrombin begins to appear after about I minute although its subsequent rate of production is not increased. It seems probable that this autocatalytic property of thrombin is due to its capacity to accelerate the production of thromboplastin, an activity that can readily be demonstrated by means of the thromboplastin generation test (see Fig. 5). Quick (195I) and Stefanini (I95I) believe that thrombin accelerates its own formation by causing platelet disruption, so increasing thromboplastin production. The rate at which thrombin produces detectable changes in the platelets is relatively slow and the quantity of thrombin required to produce these changes is very much greater than that found bo Biggs, Douglas and Macfarlane (1953a) to be re? quired to accelerate thromboplastin generation. It seems doubtful therefore whether the action of thrombin on the platelets is an important cause of the autocatalytic action of thrombin.

\section{The Conversion of Fibrinogen to Fibrin}

Fibrin begins to appear as soon as thrombin is detectable in the blood. The action of thrombin in converting fibrinogen to fibrin is probably enzymatic. Although not essential, both calcium and the products of platelet disintegration (platelet factor II) appear to enhance the activity of thrombin. It has been suggested (Tocantins, I952; Owren, 1952) that fibrin may increase thromboplastin production by forming an extensive waterwettable surface. Fibrin on the other hand adsorbs large quantities of thrombin, thus acting as a potent antithrombin.

In conclusion, it will be seen that blood coagulation involves several complex mechanisms. These are summarized in Fig. 6. Some of these mechanisms tend to increase clotting and others to hold it in check. The factors which determine the resultant of these opposing forces are ill understood, and it is clear that many of the views expressed here may have to be modified as further discoveries are made in this rapidly advancing field. 
The author is indebted to Dr. Rosemary Biggs and Dr. R. G. Macfarlane for their criticisms of the manuscript and to the Medical Research Council for a grant for expenses.

\section{BIBLIOGRAPHY}

ACKROYD, J. F. (1949a), Clin. Sci., 7, 249.

ACKROYD, J. F. (1949b), Ibid., 8, 235.

ADDIS, T. (1911), f. Path. Bact., 15, 427.

AGGELER, P. M., WHITE, S. G., GLENDENNING, M. B., PAGE, E. W., LEAKE, T. B., and BATES, G. (1952), Proc. Soc. Exper. Biol. and Med., N.Y., 79, 692.

ALEXANDER, B., GOLDSTEIN, R., and LANDWEHR, G. (1950), Ұ. Clin.' Invest., 29, $88 \mathrm{I}$.

ALEXANDER, B., GOLDSTEIN, R., LANDWEHR, G., and COOK, C. D. (1951), Ibid., 30, 596.

ALEXANDER, B., DE VRIES, A., and GOLDSTEIN, R. (1949), Blood, 4, 739.

ARTHUS, M., and CHAPIRO, T. (1908), Arch. int. Physiol., 6, 298.

ASTRUP, T., and PERMIN, P. M. (1948), Nature, 16r, 689.

BEAUMONT, J. L., and BERNARD, J. (1953), Acta med. scand., I45, 200.

BIDWELL, E., and MACFARLANE, R. G. (195I), Biochem. $\mathcal{f}$., 49, xlii.

BIGGS, R., and DOUGLAS, A. S. (1953), f. Clin. Path., 6, 23.

BIGGS, R., DOUGLAS, A. S., and MACFARLANE, R. G. (1953a), f. Physiol., 119, 89.

BIGGS, R., DOUGLAS, A. S., and MACFARLANE, R. G (I953b). Unpublished observations quoted by Biggs and Douglas, 1953 .

BIGGS, R., DOUGLAS, A. S., MACFARLANE, R. G., DACIE, J. V., PITNEY, W. R., MERSKEY, C., and O'BRIEN, J. R. (1952), Brit. med. F., ii, 1378.

BIGGS, R., and MACFARLANE, R. G. (1953a), 'Human blood coagulation and its disorders,' Blackwell, Oxford.

BIGGS, R., and MACFARLANE, R. G. (1953b), Personal communication.

BIGGS, R., MACFARLANE, R. G., and PILLING, J. (1947), Lancet, $\mathbf{i}, 402$.

BRINK, A. J., and KINGSLEY, C. S. (1952), Quart. F. Med., $65,19$.

BUDTZ-OLSEN, O. E. (195I), 'Clot retraction,' Blackwell, Oxford.

CHARGAFF, E., BENDICH, A., and COHEN, S S.. (1944), $\mathcal{f}$. Biol. Chem., 156, 161 .

COHN, E. J. (1946), Blood, I, 3.

COSGRIFF, S. W., and LEIFER, E. (1952), f. Amer. Med. Assoc., 148, 462.

CRAMER, R., MATTER, M., and LOELIGER, A. (1953), Helv. Paediat. Acta, 8, 185 .

vAN CREVELD, S., and PAULSSEN, M. M. P. (1951), Lancet, ii, 242.

VAN CREVELD, S., and PAULSSEN, M. M. P. (1952), Ibid., i, 23.

DOUGLAS, A. S. (1953), Unpublished observations quoted by Biggs and Douglas, 1953 .

FANTL, P., and NANCE, M. H. (1946), Nature, 158, 708.

FANTL, P., and NANCE, M. H. (1948), Med. F. Australia, 1, 128.

FRANK, E., BILHAN, vON N., and EKREN, H. (1950), Acta Haemat., 3, 70.

GOVAERTS, P., and GRATIA, A. (1931), Rev. Belge Sci. Med., 3, 689.

GRAHAM, J. B., PENICK, G. D., and BRINKHOUS, K. M. (1951), Am. Ұ. Physiol., 164, 710.

HOWELL, W. H., and CEKADA, E. B. (1926), Ibid., 78, 500.

JÜRGENS, J. (1953), Communication to the Fourth Congress of the European Society of Haematology.

KLEIN, P. D., and SEEGERS, W. H. (1950), Blood, 5, 742.

KOLLER, F. (1953), Communication to the Fourth Congress of the European Society of Haematology.

KOLLER, F., KRÜSI, G., and LUCHSINGER, P. (1950), Schweiz. med. Wschr., 80, 1 101.
KOLLER, F., LOELIGER, A., and DUCKERT, F. (1951), Acta Haemat., 6, I.

KOLLER, F., LOELIGER, A., and DUCKERT, F. (1952), Rev. Hématol., 7, 156 .

LEWIS, J. H., and FERGUSON, J. H. (1953), Proc. Soc. Exp. Biol. and Med., N.Y., 82, 445 .

LYTTLETON, J. W. (1950), Thesis for degree of Ph.D., University of London.

MACFARLANE, R. G. (1953), Lecture 13 in 'Lectures on the scientific basis of medicine, I95 I-52,' London.

MACFARLANE, R. G., and BIGGS, R. (1946), Lancet, ii, 862

MOLE, R. H. (1948), F. Path. Bact., 60, 413.

MORAWITZ, P. (1905), Ergebn. Physiol., 4, 307.

DE NICOLA, P. (1953), Blood, 8, 947.

NOLF, P. (1908), Arch. Int. Physiol., 6, r.

OWEN, C. A., and BOLlMAN, J. L. (1948), Proc. Soc. Exper. Biol. and Med., N.Y., 67, 231

OWREN, P. A. (1944), Det Norske videnskaps-akademi i Oslo, Árbok, 2I.

OWREN, P. A. (1947), ' The coagulation of blood. Investigations on a new clotting factor,' Gundersen, Oslo.

OWREN, P. A. (1950a), 'International Society of Haematology Third International Congress, Cambridge,' Grune \& Stratton, New York, p. 379.

OWREN, P. A. (1950b), Ibid., p. 475.

OWREN, P. A. (1951), Scand. F. Clin. Lab. Invest., 3, 168.

OWREN, P. A. (1952), 'Handbook of biological data,' Saunders, Philadelphia.

OWREN, P. A. (1953), Am. F. Med., 14, 201.

PATEK, A. J., and STETSON, R. P. (1936), f. Clin. Invest., I5. $53 \mathrm{I}$.

PATTON, T. B., WARE, A. G., and SEEGERS, W. H. (1948) Blood, 3, 656.

PAVLOVSKY, A. (1947), Ibid., 2, 185.

POOLE, J. C. F. (1953), Lancet, i, 122.

QUICK, A. J. (1935), F. Biol. Chem., ro9, ' Scientific proceedings xxix, p. Ixxiii.

QUICK, A. J. (1938), Amer. F. Physiol., 123, 712.

QUICK, A. J. (1943), Ibid., 140, 212.

QUICK, A. J. (195I), 'The physiology and pathology of haemostasis,' London.

ROSENTHAL, R. L., DRESKIN, O. H., and ROSENTHAL, $\mathbf{N}$. (1953), Proc. Soc. Exp. Biol. and Med., N.Y., 82, 171.

SCHMIDT, A. (1892), Quoted by Morawitz (1905).

SCHOFIELD, F. W. (1924), F. Amer. Vet. Med. Ass., 64, 553.

SCHULMAN, I., and SMITH, C. H. (1952), Blood 7, 794.

SEEGERS, W. H., MCCLAUGHRY, R. I., and FAHEY, J. L. (1950), Ibid., 5, 421 .

LE SOURD, L., and PAGNIEZ, P. (1911), F. Physiol. Path. Gén., 13, 56 .

STEFANINI, M. (195I), Acta med. Scand., 140, 290.

STOHLMAN, F., HARRINGTON, W. J., and MOLONEY, W. C. (1951), 'f. Lab. Clin. Med., 38, 842 .

TOCANTINS, L. M. (1934), Amer. Ұ. Physiol., 110, 278.

TOCANTINS, L. M. (1952), 'Handbook of biological data, Saunders, Philadelphia.

DE VRIES, A., ALEXANDER, B., and GOLDSTEIN, R. (1949), Blood, 4, 247.

DE VRIES, A., MATOTH, Y., and SHAMIR, Z. (1951), Acta Haemat., 5, 129.

WARE, A. G., FAHEY, J. L., and SEEGERS, W. H. (1948), Am. F. Physiol., 154, 140.

WARE, A. G., GUEST, M. M., and SEEGERS, W. H. (1947), F. Biol. Chem., 169, 231 .

WARE, A. G., and SEEGERS, W. H. (1948), Ibid., 172, 699.

WARNER, E. D., BRINKHOUS, K. M., and SMITH, H. P (1936), Am. ̈. Physiol., 114, 667 .

WEIL, P. E. (1906), Bull. Soc. Méd. Hop., Paris, 23, 1001. 